\section{Quantity and Quality of Cuttings as Influenced by Stock Plant Nutrition of Herbaceous Perennials}

\author{
Christina M. Twardowski, Jaime L. Crocker, John R. Freeborn, \\ and Holly L. Scoggins ${ }^{1}$
}

ADDITIONAL INDEX WORDs. propagation, nitrogen rate, dianthus, gaura, salvia, perovskia

SUMMARY. Some popular garden perennials yield low numbers of viable cuttings per stock plant or produce cuttings that are slow to root, preventing propagators from meeting demand for rooted liners. We quantified the effects of a range of nitrogen (N) rates from 0 to $300 \mathrm{mg} \cdot \mathrm{L}^{-1} \mathrm{~N}$ applied to stock plants on the number of cuttings (yield), rooting percentage, and subsequent root development of cuttings. Species studied include 'Siskiyou Pink' gaura (Gaura lindheimeri), 'Pixie Star' dianthus (Dianthus alpinus), perovskia (Perovskia atriplicifolia), and 'Mainacht' salvia (Salvia $\times$ sylvestris). We found 100 to $150 \mathrm{mg} \cdot \mathrm{L}^{-1} \mathrm{~N}$ to be the best rates for producing quality rooted cuttings. Little benefit was obtained from the higher rates, and the 0 and $50-\mathrm{mg} \cdot \mathrm{L}^{-1} \mathrm{~N}$ treatments produced the lowest number of potential cuttings across all species.

$\mathrm{M}$ any perennial growers maintain their own stock plants to produce cuttings for rooting as a cost-effective alternative to ordering in rooted liners. However, a number of widely grown herbaceous perennial species are difficult to propagate; stock plants yield insufficient numbers of cuttings, and cuttings have low rooting percentages and/or are slow to develop root mass (Scoggins, 2006). Discussions with propagators at a major perennial liner nursery guided our selection of four particularly problematic species. Nutrient management of stock plants has been shown to influence some or all of these propagation issues in woody plants (Cerveny et al., 2005; Henry et al., 1992; Raymer et al., 2008; Rowe et al., 1999), herbaceous annuals (Gibson, 2003), and potted flowering plants (Druege et al., 2000; Ganmore-Neumann and Hagiladi, 1992). Little information is available on stock plant nutrient management of hardy, herbaceous landscape perennials.

Gibson and Cerveny (2005) noted stock plants should be maintained with a fertilization program that will yield

Department of Horticulture, Virginia Tech, Blacksburg, VA 24061

Funding for this project was provided by the Fred C. Gloeckner Foundation, Inc. We also thank Green Leaf Plants $^{\circledR}$, Aris Horticulture Inc., and Conrad Fafard, Inc. for their support of floriculture research at Virginia Tech.

${ }^{1}$ Corresponding author. E-mail: perennials@vt.edu. cuttings with sufficient nutrient reserves until rooting occurs. Most work in the area of nutrient effects on stock plant cutting yield and rooting response has been done on conifers, annuals, or flowering potted plants. Increasing stock plant nitrogen levels had a negative impact on rooting percentage and adventitious root development of cuttings of loblolly pine [Pinus taeda (Rowe et al., 1999)]. When a range of $\mathrm{N}$ rates $\left(10\right.$ to $\left.640 \mathrm{mg} \cdot \mathrm{L}^{-1} \mathrm{~N}\right)$ was applied to eastern redcedar (Juniperus virginiana) stock plants, rooting response was optimized at the relatively low rate of $20 \mathrm{mg} \cdot \mathrm{L}^{-1} \mathrm{~N}$; subsequent increases in $\mathrm{N}$ rate caused root counts and dry weight of rooted cuttings to decline (Henry et al., 1992). Alternatively, Gibson's (2003) work with vegetative annuals including 'Grenada' new guinea impatiens (Impatiens Xhawkeri) and 'Purple Fan' scaevola (Scaevola aemula) found the highest

\begin{tabular}{llll}
\hline $\begin{array}{l}\text { Units } \\
\begin{array}{l}\text { To convert U.S. to SI, } \\
\text { multiply by }\end{array}\end{array}$ & U.S. unit & SI unit & $\begin{array}{l}\text { To convert SI to U.S., } \\
\text { multiply by }\end{array}$ \\
\hline 29.5735 & $\mathrm{fl} \mathrm{oz}$ & $\mathrm{mL}$ & 0.0338 \\
3.7854 & gal & $\mathrm{L}$ & 0.2642 \\
6.4516 & inch $^{2}$ & $\mathrm{~cm}^{2}$ & 0.1550 \\
16.3871 & inch $^{3}$ & $\mathrm{~cm}^{3}$ & 0.0610 \\
0.5933 & lb $/ \mathrm{yard}^{3}$ & $\mathrm{~kg} \cdot \mathrm{m}^{-3}$ & 1.6856 \\
1 & $\mathrm{mmho} / \mathrm{cm}$ & $\mathrm{dS} \cdot \mathrm{m}^{-1}$ & 1 \\
28,350 & $\mathrm{oz}$ & $\mathrm{mg}$ & $3.5274 \times 10^{-5}$ \\
1 & $\mathrm{ppm}$ & $\mathrm{mg} \cdot \mathrm{L}^{-1}$ & 1 \\
6.8948 & $\mathrm{psi}$ & $\mathrm{kPa}$ & 0.1450 \\
0.9464 & $\mathrm{qt}$ & $\mathrm{L}$ & 1.0567 \\
$\left({ }^{\circ} \mathrm{F}-32\right) \div 1.8$ & $\mathrm{o} F$ & ${ }^{\circ} \mathrm{C}$ & $\left(1.8 \times{ }^{\circ} \mathrm{C}\right)+32$
\end{tabular}

rate of $\mathrm{N}$ applied to stock plants (300 $\mathrm{mg} \cdot \mathrm{L}^{-1} \mathrm{~N}$, from a range of 100 to 300 $\mathrm{mg} \cdot \mathrm{L}^{-1} \mathrm{~N}$ ) produced the most cuttings with the best rooting performance. Hardy herbaceous perennials have a slower growth rate than vegetative annuals but faster than conifers; therefore, the optimum $\mathrm{N}$ rate may lie in between.

Druege et al. (2000) established that increasing fertilizer $\mathrm{N}$ rate as applied to stock plants increased foliar $\mathrm{N}$ in cuttings for chrysanthemum (Dendranthemaxgrandiflorum), which in turn positively correlated to the number and length of adventitious roots (rooting percentage was not measured). However, little correlation existed between stock plant foliar $\mathrm{N}$ and rooting responses measured (percent, count, length, dry weight) in eastern redcedar (Henry et al., 1992). Manipulation of $\mathrm{N}$ rate of stock plants may not be the only way to impact rooting of the cuttings using fertility. Adding controlledrelease fertilizer to the rooting substrate of cuttings of several herbaceous perennial species did not impact rooting percentage but did increase shoot mass and root number of cuttings that rooted (Rowe and Cregg, 2002). Ganmore-Neumann and Hagiladi (1992) found $\mathrm{N}$ form (ammonium- $\mathrm{N}$ vs. nitrate-N) did not affect yield of cuttings in pelargonium (Pelargonium $\times$ hortorum). Increasing fertilizer $\mathrm{N}$ rate did not result in significantly more cuttings though the authors noted the $50-\mathrm{mg} \cdot \mathrm{L}^{-1} \mathrm{~N}$ treatment resulted in the least number of cuttings. Effect of $\mathrm{N}$ rate on rooting was not tested.

On the basis of the current literature, we believe the most likely impact of nutrition on rooting would be while the stock plants were growing. Our objective was to determine if manipulation of $\mathrm{N}$ rates as applied to stock plants would enhance the quantity of cuttings and quality of rooting for 
several perennials reputed to be difficult to propagate.

\section{Materials and methods}

Two experiments were carried out: Fall 2006/Winter 2007 (Expt. 1) and late Spring 2008 (Expt. 2). Materials and methods common to both experiments are described first, followed by differences between the experiments (fertilizer rates, timeline, and greenhouse environment).

STOCK PLANT PRODUCTION. For both experiments, rooted liners of 'Siskiyou Pink' gaura, 'Pixie Star' dianthus, and 'Mainacht' salvia were received from Green Leaf Plants ${ }^{\circledR}$ (Aris Horticulture, Lancaster, PA). Perovskia was added to species tested in Expt. 2 from the same source. Liners were irrigated with clear water (no fertilizer) for 1 week, then sorted for uniformity, and planted one per 1 -qt pot $(917 \mathrm{~mL})$ and placed on the greenhouse bench. The growing substrate was $50 \%$ peatbased Fafard 3-B (Conrad Fafard, Agawam, MA) and 50\% pine bark (v:v). The substrate was custom manufactured without added nutrients. Dolomitic lime was added at a rate of $2.7 \mathrm{~kg} \cdot \mathrm{m}^{-3}$ to adjust substrate $\mathrm{pH}$ to 6.2. Plants were arranged in a complete randomized design with six replications per treatment per species.

Fertilizer treatments. The fertilizer solutions were custom-made with (in $\mathrm{mg} \cdot \mathrm{L}^{-1}$ ) 8.7 phosphorous, 166 potassium, 92 calcium, 40 magnesium, and 34 sulfur from calcium chloride, monoammonium phosphate, magnesium phosphate, magnesium sulfate, potassium nitrate, and micronutrients from Scotts S.T.E.M. (Soluble Trace Element Mix; Scotts, Marysville, $\mathrm{OH}$ ), added at a rate of $7 \mathrm{mg} \cdot \mathrm{L}^{-1}$. In Expt. 1 , all $\mathrm{N}$ treatments were developed using ammonium nitrate. In Expt. 2, the $50-\mathrm{mg} \cdot \mathrm{L}^{-1} \mathrm{~N}$ treatment was developed using calcium nitrate, and all higher nitrogen rates were obtained via addition of the appropriate amount of ammonium nitrate to the $50-\mathrm{mg} \cdot \mathrm{L}^{-1}$ $\mathrm{N}$ rate.

Volumetric substrate moisture was measured daily with a Delta $\mathrm{HH} 2$ Soil Moisture Meter/Theta Probe (Delta-T Devices, Cambridge, UK). Plants were watered when volumetric substrate moisture fell below $25 \%$ for dianthus and $30 \%$ for gaura, perovskia, and salvia. Substrate electrical conductivity (EC) was monitored weekly via direct-stick probe (Field Scout Direct
EC Meter; Spectrum Technologies, Plainfield, IL). Fertilizer solution was applied at a sufficient volume to produce adequate leaching fraction at each watering until substrate EC approximated the EC levels of the respective fertilizer solution treatment. Once cuttings were harvested, recently matured leaves were removed from the stock plants, dried, ground, and sent to Quality Analytical Laboratories (Panama City, FL) for nutrient analysis. To create a large enough sample for $\mathrm{N}$ analysis, tissue had to be combined from all replications of each treatment/species combination; thus, statistical analysis could not be conducted.

Propagation from cuttings. The number of potential cuttings from each stock plant was determined after the start of treatments as noted in the timelines. A cutting was defined as having at least two nodes, with the first node occurring below a recently matured leaf. A maximum of 10 cuttings were taken at random from each stock plant (numbers were limited because of mist bench space constraints) for a maximum of 60 cuttings per species per treatment combination. Cuttings were dipped for $5 \mathrm{~s}$ in a water-based solution of $1500 \mathrm{mg} \cdot \mathrm{L}^{-1}$ indole-3-butyric acid (upper value of range of rates recommended for use on unrooted cuttings by Green Leaf Plants ${ }^{\circledR}$ ) and then stuck in 128-cell trays filled with a mixture of $70 \%$ of the previously described peat/pine bark substrate and 30\% perlite $(\mathrm{v} / \mathrm{v})$. Trays were placed under an intermittent mist system to allow rooting. No additional fertilizer was applied, nor was there a starter charge in the substrate. The number of rooted cuttings was determined when roots were visible from the bottom of the cell for the majority of treatments. Rooted cuttings were washed free of substrate, and then total root volume and root surface area were determined using the WinRHIZO image analysis system (Regent Instruments, Quebec, QC, Canada). The WinRHIZO system is suitable for fine roots as it has the capacity to detect overlapping root parts and to compensate for them in the final results (Arsenault et al., 1995). Root measurement data were analyzed by Analysis of Variance Procedure of SAS and subjected to regression analysis using SAS General Linear Models Procedure (version 9.2;
SAS Institute, Cary, NC). Rooting percentage data were transformed (arcsin), and analysis was performed by logistic regression (JMP 8.0, SAS Institute).

Greenhouse environment. Both studies were performed in the same glass greenhouse in Blacksburg, VA (lat. $37.23^{\circ} \mathrm{N}$, long. $80.42^{\circ} \mathrm{W}$ ). During rooting of cuttings, the mist interval was controlled by a digital timer and adjusted daily by hand based on weather conditions and stage of plug development. All cuttings were on the same system, using Ein-Dor 809 Omni misters ( $30 \mathrm{gal} / \mathrm{h}$ at $30 \mathrm{psi}$; Agridor, Rosh Ha'ayin, Israel).

EXPT. 1 TIMELINE, TREATMENTS, AND ENVIRONMENT. Rooted liners of dianthus and gaura were received 16 Sept. 2006 and salvia 7 Dec. 2006. Fertilizer treatments began $20 \mathrm{~d}$ after transplant. Potential cuttings were counted and cuttings taken $108 \mathrm{~d}$ (dianthus), $162 \mathrm{~d}$ (gaura), and $95 \mathrm{~d}$ (salvia) after the start of fertilizer treatments. Rooting percentages were determined and root measurements taken $28 \mathrm{~d}$ after sticking cuttings. Fertilizer treatments were comprised of four rates: 0,100 , 200 , and $300 \mathrm{mg} \cdot \mathrm{L}^{-1} \mathrm{~N}$. Greenhouse light levels averaged $11.9 \mathrm{~mol} \cdot \mathrm{m}^{-2} \cdot \mathrm{d}^{-1}$ and temperatures averaged $69.5^{\circ} \mathrm{F}$.

EXPT. 2 TIMELINE, TREATMENTS, AND ENVIRONMENT. Rooted liners were received 22 May 2008. Fertilizer treatments began $20 \mathrm{~d}$ after transplant. The stock plants increased in mass much more rapidly than during Expt. 1, probably due to longer daylength and warmer temperatures. Potential cuttings were counted, and cuttings were taken $63 \mathrm{~d}$ after the start of fertilizer treatments. On the basis of results from Expt. 1, cuttings were allowed a longer rooting period. Rooting percentages were determined, and root measurements were taken $44 \mathrm{~d}$ after sticking cuttings for dianthus and gaura and $45 \mathrm{~d}$ after sticking for perovskia and salvia. Fertilizer treatments were comprised of five rates: 50,100,150, 200, and $250 \mathrm{mg} \cdot \mathrm{L}^{-1} \mathrm{~N}$. Based on results of Expt. l, we found the stock plants of the same species fertilized with either 0 or $300 \mathrm{mg} \cdot \mathrm{L}^{-1} \mathrm{~N}$ performed poorly in terms of survival, plant size, and potential number of cuttings and most performed best between 100 and 200, hence the choice of a wider range of lower rates for Expt. 2. For Expt. 2 (late spring/early summer), the glass 
house was painted with white shade to reduce light levels. Greenhouse light levels averaged $13.8 \mathrm{~mol} \cdot \mathrm{m}^{-2} \cdot \mathrm{d}^{-1}$ and temperatures averaged $77^{\circ} \mathrm{F}$.

\section{Results}

Dianthus. There was a significant increase in the number of potential cuttings as $\mathrm{N}$ rate increased in both experiments (Tables 1 and 2 ). Though the stock plants were smaller overall in Expt. 2, the same trend appeared. Increasing $\mathrm{N}$ rate did result in an increase in percent rooting in Expt. 1; however, the largest change was from 0 to $100 \mathrm{mg} \cdot \mathrm{L}^{-1} \mathrm{~N}$ (Table 3 ). There was no rate effect on percent rooting in Expt. 2 though rooting percentage decreased at the higher rates of 200 to $250 \mathrm{mg} \cdot \mathrm{L}^{-1} \mathrm{~N}$ (Table 4 ). The $100-\mathrm{mg} \cdot \mathrm{L}^{-1} \mathrm{~N}$ treatments yielded the greatest root surface area in both

Table 1. Effect of nitrogen $(\mathrm{N})$ rate on number of potential cuttings per stock plant as measured after the start of the $\mathrm{N}$-rate treatments for dianthus (180 d), gaura (162 d), and salvia (95 d) in Expt. $1(n=6)$.

\begin{tabular}{|c|c|c|c|}
\hline \multirow{2}{*}{$\begin{array}{l}\text { N rate } \\
\left(\mathrm{mg} \cdot \mathrm{L}^{-1}\right)^{\mathrm{z}}\end{array}$} & \multicolumn{3}{|c|}{ Potential cuttings (no.) } \\
\hline & Dianthus & Gaura & Salvia \\
\hline 0 & 25.0 & 1.8 & 一 \\
\hline 100 & 59.7 & 17.0 & 7.3 \\
\hline 200 & 90.7 & 17.3 & 9.3 \\
\hline 300 & 94.3 & 17.3 & 3.5 \\
\hline Rate effect ${ }^{\mathrm{y}}$ & $* * *$ & $* * *$ & ** \\
\hline $\mathrm{LSD}^{\mathrm{w}}$ & 14.8 & 6.4 & 一 \\
\hline Linear $^{y}$ & $* * *$ & ** & NS \\
\hline Quadratic $^{\mathrm{y}}$ & $* * *$ & *** & ** \\
\hline
\end{tabular}

experiments (Tables 5 and 6) and the greatest root volume in Expt. 1 (Table 5 ) though root volume was unaffected by rate in Expt. 2 (Table 6 ). In both experiments, stock plants receiving the highest $\mathrm{N}$ treatments deteriorated rapidly after the cuttings were taken, indicating a possible intolerance to higher substrate EC (Table 7).

Gaura. There was little impact of $\mathrm{N}$ rate on the number of potential cuttings. As with dianthus, the greatest change in Expt. 1 occurred from 0 to $100 \mathrm{mg} \cdot \mathrm{L}^{-1} \mathrm{~N}$ (Table 1); there was no impact in Expt. 2 (Table 2). Rooting percentage was greatest at $200 \mathrm{mg} \cdot \mathrm{L}^{-1}$ $\mathrm{N}$ in Expt. 1 (Table 3 ) but at the higher rates $\left(200\right.$ and $\left.250 \mathrm{mg} \cdot \mathrm{L}^{-1} \mathrm{~N}\right)$ in Expt. 2 , and rooting percentages dropped off $20 \%$ and $25 \%$, respectively, when compared with $100-\mathrm{mg} \cdot \mathrm{L}^{-1} \mathrm{~N}$ treatments (Table 4). Root surface area and volume for gaura in both experiments were significantly impacted by $\mathrm{N}$ rate but appear to be optimized around $200 \mathrm{mg} \cdot \mathrm{L}^{-1} \mathrm{~N}$ and then decrease at higher $\mathrm{N}$ rates, with the exception of Expt. 1 root surface area (Tables 5 and 6).

Perovskia. Nitrogen rate affected both number of potential cuttings and rooting performance in Expt. 2 . The $200-\mathrm{mg} \cdot \mathrm{L}^{-1} \mathrm{~N}$ rate produced the greatest number of potential cuttings (Table 2) and also the greatest rooting percentage (Table 4 ). Rooting percentage was $80 \%$ or better for all treatments. However, there was a strong linear decrease in root volume and surface area as the $\mathrm{N}$ rate increased from $50 \mathrm{mg} \cdot \mathrm{L}^{-1}$ (Table 6).

Salvia. Plants produced few potential cuttings Expt. 1, with none produced at $0 \mathrm{mg} \cdot \mathrm{L}^{-1} \mathrm{~N}$ (Table 1$)$.

Table 2. Effect of nitrogen $(\mathrm{N})$ rate on number of potential cuttings per stock plant as measured $63 \mathrm{~d}$ after the start of the $\mathrm{N}$-rate treatments for dianthus, gaura, perovskia, and salvia in Expt. $2(n=6)$.

\begin{tabular}{|c|c|c|c|c|}
\hline \multirow{2}{*}{$\begin{array}{l}\text { N rate } \\
\left(\mathrm{mg} \cdot \mathrm{L}^{-1}\right)^{\mathrm{z}}\end{array}$} & \multicolumn{4}{|c|}{ Potential cuttings (no.) } \\
\hline & Dianthus & Gaura & Perovskia & Salvia \\
\hline 50 & 16.2 & 9.5 & 10.0 & 8.7 \\
\hline 100 & 25.5 & 16.2 & 22.2 & 22.8 \\
\hline 150 & 22.8 & 13.7 & 14.0 & 21.3 \\
\hline 200 & 24.3 & 17.0 & 16.5 & 29.2 \\
\hline 250 & 31.2 & 14.7 & 16.2 & 22.8 \\
\hline Rate effect ${ }^{y}$ & *** & NS & ** & ** \\
\hline $\mathrm{LSD}^{\mathrm{w}}$ & 5.4 & 6.5 & 5.8 & 9.9 \\
\hline Linear $^{y}$ & *** & NS & NS & ** \\
\hline Quadratic $^{\mathrm{y}}$ & $* * *$ & NS & NS & ** \\
\hline
\end{tabular}

${ }^{\mathrm{z}} \mathrm{l} \mathrm{mg} \cdot \mathrm{L}^{-1}=1 \mathrm{ppm}$.

${ }^{\mathrm{y}} \mathrm{NS},{ }^{*}, * *, * * *$ Nonsignificant or significant at $P \leq 0.05,0.01$, or 0.001 , respectively, based on ANOVA.

wLeast significant difference, Student's $t$ test at $P \leq 0.05$.

The most potential cuttings were produced at $200 \mathrm{mg} \cdot \mathrm{L}^{-1} \mathrm{~N}$. In Expt. 2, the plants fared much better. Stock plants receiving $100 \mathrm{mg} \cdot \mathrm{L}^{-1} \mathrm{~N}$ and higher rates produced more potential cuttings than the $50-\mathrm{mg} \cdot \mathrm{L}^{-1} \mathrm{~N}$ treatment, but there was little difference among rates greater than $50 \mathrm{mg} \cdot \mathrm{L}^{-1}$ $\mathrm{N}$ (Table 2). Rooting percentage was variable though rates higher than 200 $\mathrm{mg} \cdot \mathrm{L}^{-1} \mathrm{~N}$ resulted in decreased rooting percentages for both experiments. Root surface area and volume were not significantly affected by $\mathrm{N}$ rate in either experiment though slightly greater volume and surface area were observed with 150 and $200 \mathrm{mg} \cdot \mathrm{L}^{-1} \mathrm{~N}$ in both experiments (Tables 5 and 6 ).

\section{Discussion}

Although general recommendations are easier for growers to follow, perennials seem to vary widely in response to varying fertilizer rates (Scoggins, 2005). Regarding the number of potential cuttings, stock plant $\mathrm{N}$ rate affected all species in both experiments except for gaura in Expt. 2. Dianthus was most responsive to increasing $\mathrm{N}$ rates, but the high $\mathrm{EC}$ resulted in rapid decline of the stock plants. In work on poinsettia (Euphorbia pulcherrima), three $\mathrm{N}$ fertilization rates were administered in "graduated doses" (milligrams of $\mathrm{N}$ per container) and described as low (0-40 $\mathrm{mg} \mathrm{N}$ ), medium (72-100 $\mathrm{mg} \mathrm{N})$ and high (150-300 mg N) (Zerche and Druege, 2009). They reported the low and high $\mathrm{N}$ rates interfered with the growth of stock plants by either causing an $\mathrm{N}$ deficiency (visible symptoms were noted) or too high of a substrate EC ("unfavorable osmotic environment") of the stock plants. The most obvious trend was the increase in quantity of potential cuttings from the lowest rates to moderate rates (e.g., from 0 to

Table 3. Effect of nitrogen $(\mathrm{N})$ rate on percent rooting of dianthus, gaura, and salvia as measured $28 \mathrm{~d}$ after sticking cuttings in Expt. 1.

\begin{tabular}{lccc}
\hline \multirow{2}{*}{$\begin{array}{l}\text { N rate } \\
\left(\mathbf{m g} \cdot \mathbf{L}^{-\mathbf{1}}\right)^{\mathrm{z}}\end{array}$} & \multicolumn{3}{c}{ Cuttings rooted (\%) } \\
\cline { 2 - 4 } & Dianthus & Gaura & Salvia \\
\hline 0 & 75 & 33 & - \\
100 & 100 & 57 & 30 \\
200 & 98 & 92 & 44 \\
300 & 100 & 85 & 20 \\
Rate effect $^{\mathrm{y}}$ & $* * *$ & $* *$ & $\mathrm{NS}$ \\
\hline
\end{tabular}

${ }^{\mathrm{z}} \mathrm{l} \mathrm{mg} \cdot \mathrm{L}^{-1}=1 \mathrm{ppm}$.

${ }_{\mathrm{NS}},{ }^{*},{ }^{* *},{ }^{* *}$ Nonsignificant or significant at $P \leq$ $0.05,0.01$, or 0.001 , respectively, based on ANOVA. 
Table 4. Effect of nitrogen $(\mathrm{N})$ rate on percent rooting of as measured $44 \mathrm{~d}$ after sticking cuttings for dianthus and gaura, and $\mathbf{4 5} \mathrm{d}$ after sticking for perovskia and salvia in Expt. 2.

\begin{tabular}{lcccc}
\hline & \multicolumn{4}{c}{ Cuttings rooted $(\%)$} \\
\cline { 2 - 5 } N rate $\left(\mathbf{m g} \cdot \mathbf{L}^{-\mathbf{1}}\right)^{\mathbf{z}}$ & Dianthus & Gaura & Perovskia & Salvia \\
\hline 50 & 30 & 73 & 80 & 80 \\
100 & 45 & 88 & 92 & 70 \\
150 & 45 & 74 & 85 & 79 \\
200 & 15 & 68 & 80 & 60 \\
250 & 25 & 63 & 90 & 59 \\
Rate effect $^{y}$ & NS & $* *$ & $* *$ & $* * *$ \\
\hline
\end{tabular}

${ }^{2} 1 \mathrm{mg} \cdot \mathrm{L}^{-1}=1 \mathrm{ppm}$.

${ }^{\mathrm{NS}},{ }^{*},{ }^{* *},{ }^{* * *}$ Nonsignificant or significant at $P \leq 0.05,0.01$, or 0.001 , respectively, based on ANOVA.

Table 5. Effect of nitrogen $(\mathrm{N})$ rate on cutting root surface area and cutting root volume as measured $28 \mathrm{~d}$ after sticking for dianthus, gaura, and salvia (no salvia cuttings rooted at $0 \mathrm{mg} \cdot \mathrm{L}^{-1} \mathrm{~N}$ ) in Expt. 1 .

\begin{tabular}{|c|c|c|c|c|c|c|}
\hline \multirow[b]{2}{*}{$\mathrm{N}$ rate $\left(\mathrm{mg} \cdot \mathrm{L}^{-1}\right)^{\mathrm{z}}$} & \multicolumn{3}{|c|}{ Root surface area $\left(\mathrm{cm}^{2}\right)^{\mathrm{z}}$} & \multicolumn{3}{|c|}{$\operatorname{Root} \operatorname{vol}\left(\mathrm{cm}^{3}\right)^{\mathrm{z}}$} \\
\hline & Dianthus & Gaura & Salvia & Dianthus & Gaura & Salvia \\
\hline 0 & 1.98 & 1.21 & - & 0.03 & 0.03 & - \\
\hline 100 & 13.0 & 13.2 & 11.0 & 0.55 & 0.34 & 0.21 \\
\hline 200 & 10.9 & 13.3 & 12.5 & 0.32 & 0.40 & 0.32 \\
\hline 300 & 9.04 & 14.9 & 11.8 & 0.28 & 0.38 & 0.26 \\
\hline Rate effect ${ }^{y}$ & $* * *$ & $* * *$ & NS & $* * *$ & ** & NS \\
\hline Linear $^{\mathrm{y}}$ & $* * *$ & ** & NS & NS & NS & NS \\
\hline Quadratic $^{y}$ & $* * *$ & ** & NS & $* * *$ & ** & NS \\
\hline
\end{tabular}

$1 \mathrm{mg} \cdot \mathrm{L}^{-1}=1 \mathrm{ppm}, 1 \mathrm{~cm}^{2}=0.1550$ inch $^{2}, 1 \mathrm{~cm}^{3}=0.0610$ inch $^{3}$.

${ }_{\mathrm{NS}},{ }^{*},{ }^{* *},{ }^{* *}$ Nonsignificant or significant at $P \leq 0.05,0.01$, or 0.001 , respectively, based on ANOVA

Table 6. Effect of nitrogen $(\mathrm{N})$ rate on cutting root surface area and cutting root volume as measured $44 \mathrm{~d}$ after sticking for dianthus, gaura, perovskia, and salvia in Expt. 2.

\begin{tabular}{|c|c|c|c|c|c|c|c|c|}
\hline \multirow{2}{*}{$\begin{array}{l}\mathrm{N} \text { rate } \\
\left(\mathrm{mg} \cdot \mathrm{L}^{-1}\right)^{\mathrm{z}}\end{array}$} & \multicolumn{4}{|c|}{ Root surface area $\left(\mathrm{cm}^{2}\right)^{\mathrm{z}}$} & \multicolumn{4}{|c|}{$\operatorname{Root} \operatorname{vol}\left(\mathrm{cm}^{3}\right)^{\mathrm{z}}$} \\
\hline & Dianthus & Gaura & Perovskia & Salvia & Dianthus & Gaura & Perovskia & Salvia \\
\hline 50 & 3.02 & 10.3 & 11.0 & 4.41 & 0.11 & 0.20 & 0.28 & 0.16 \\
\hline 100 & 3.17 & 13.7 & 7.07 & 5.11 & 0.12 & 0.29 & 0.16 & 0.17 \\
\hline 150 & 2.25 & 16.3 & 7.60 & 7.42 & 0.08 & 0.32 & 0.15 & 0.22 \\
\hline 200 & 2.71 & 18.6 & 4.67 & 7.12 & 0.13 & 0.34 & 0.10 & 0.18 \\
\hline 250 & 1.34 & 13.0 & 4.5 & 4.69 & 0.05 & 0.26 & 0.10 & 0.16 \\
\hline Rate effect ${ }^{y}$ & NS & ** & $* * *$ & NS & NS & ** & $* * *$ & NS \\
\hline Linear $^{\mathrm{y}}$ & * & * & $* * *$ & NS & NS & NS & $* * *$ & NS \\
\hline Quadratic $^{\mathrm{y}}$ & NS & $* * *$ & $* * *$ & NS & NS & ** & ** & NS \\
\hline
\end{tabular}

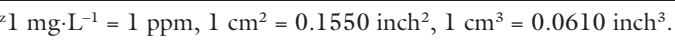

$\mathrm{y}_{\mathrm{NS}},{ }^{*},{ }^{* *},{ }^{* *}$ Nonsignificant or significant at $P \leq 0.05,0.01$, or 0.001 , respectively, based on ANOVA.

$100 \mathrm{mg} \cdot \mathrm{L}^{-1} \mathrm{~N}$ in Expt. $\mathrm{l}$ and 50 to $100 \mathrm{mg} \cdot \mathrm{L}^{-1} \mathrm{~N}$ in Expt. 2). Decreased cutting production and signs of salinity damage in pelargonium stock plants occurred when grown at relatively high $\mathrm{N}$ concentration $\left(400 \mathrm{mg} \cdot \mathrm{L}^{-1} \mathrm{~N}\right)$; however, rooting performance was not tested (Ganmore-Neumann and Hagiladi, 1992). Raymer et al. (2008) found increasing stock plant fertility to increase the number of cuttings available from seacoast marshelder ( $I v a$ imbricata), but the effect was dependent on season of harvest in this longerterm study.
Optimizing growth of stem cuttings on stock plants does not necessarily translate to better adventitious rooting and subsequent root system quality. For dianthus in both experiments and perovskia in Expt. 2, as $\mathrm{N}$ rates increased, so did the number of stem cuttings, but rooting percentages did not increase. These findings are supported by studies with different species by Henry et al. (1992) and Raymer et al. (2008). For all species in the present study, mean rooting percentage was generally highest when stock plants were treated with 100 or
$150 \mathrm{mg} \cdot \mathrm{L}^{-1}$. In other work, these results with low to moderate rates have been supported though these absolute rates were not tested specifically (GanmoreNeumann and Hagiladi, 1992; Rowe et al., 1999, 2002a). In the loblolly pine studies, $\mathrm{N}$ rates ranged from 10 to $70 \mathrm{mg} \cdot \mathrm{L}^{-1} \mathrm{~N}$, whereas in our studies study they ranged from 0 to $300 \mathrm{mg} \cdot \mathrm{L}^{-1}$ $\mathrm{N}$. Still, there was a decrease in survival of rooted cuttings at the higher $\mathrm{N}$ rates for the loblolly pine even at such low rates. The increase in $\mathrm{N}$ rate resulted in increased tissue $\mathrm{N}$ concentration for all species tested in our study (Table 7). As we did not have enough tissue to replicate these measurements, we cannot speak to statistical significance. Rowe et al. (2002a) noted tissue N concentration of stock plants increased with increasing application of $\mathrm{N}$. However, the higher tissue $\mathrm{N}$ concentration did not translate to higher rooting percentage and survival (Rowe et al., 2002b). In work with the tropical woody plant bougainvillea, Cerveny et al. (2005) grew stock plants with $\mathrm{N}$ rates of 100,200 , or $300 \mathrm{mg} \cdot \mathrm{L}^{-1} \mathrm{~N}$ found an increase in cutting yields at $200 \mathrm{mg} \cdot \mathrm{L}^{-1}$ but noted no benefit to cutting yield or diameter.

Root growth was measured in this study as root surface area and root volume. Since these two measurements were highly correlated $(r=0.93$ and greater, data not shown), the discussion will not separate the two. As with previous variables, root growth differed by species. Root growth increased as $\mathrm{N}$ rate decreased for perovskia and dianthus; moderate rates resulted in better root growth for gaura and salvia. The highest $\mathrm{N}$ rate reduced root growth in all four perennial species. Rowe et al. (2002b) found root measurements including root surface area generally increased with increases in applied $\mathrm{N}$; however, there was considerable variation in root surface area in response to increased $\mathrm{N}$ fertilizer based on the season cuttings were taken.

In commercial propagation, the yield of quality rooted cuttings is the goal. The number of cuttings harvestable from each stock plant is important, but rooting percentage and root growth combined yield a complete flat of liners. Zerche and Druege (2009) noted that adequate $\mathrm{N}$ fertilization of stock plants can affect yield and quality of cuttings and that new research is easily translated to grower fertilization strategies. Our two experiments found 
Table 7. Substrate electrical conductivity (EC) and tissue nitrogen (N) concentration for stock plants grown at a range of $\mathrm{N}$ rates. Measurements were taken at time of taking cuttings for dianthus, gaura, pervoskia (Expt. 2 only), and salvia.

\begin{tabular}{|c|c|c|c|c|c|c|}
\hline \multirow[b]{2}{*}{ Species } & \multicolumn{3}{|c|}{ Expt. 1} & \multicolumn{3}{|c|}{ Expt. 2} \\
\hline & $\begin{array}{c}\text { N rate } \\
\left(\mathrm{mg} \cdot \mathrm{L}^{-1}\right)^{\mathrm{z}}\end{array}$ & $\begin{array}{c}\text { EC } \\
\left(\mathrm{d} S \cdot \mathrm{m}^{-1}\right)^{\mathrm{z}}\end{array}$ & $\begin{array}{l}\text { N conch } \\
(\% \text { dry } w t)\end{array}$ & $\begin{array}{l}\text { N rate } \\
\left(\mathrm{mg} \cdot \mathrm{L}^{-1}\right)\end{array}$ & $\begin{array}{c}\text { EC } \\
\left(\mathrm{d} S \cdot \mathrm{m}^{-1}\right)\end{array}$ & $\begin{array}{l}\text { N conch } \\
(\% \text { dry } w t)\end{array}$ \\
\hline \multirow[t]{5}{*}{ Dianthus } & 0 & 0.25 & 3.86 & 50 & 0.91 & 2.93 \\
\hline & 100 & 0.88 & 3.05 & 100 & 1.36 & 3.21 \\
\hline & 200 & 1.20 & 4.39 & 150 & 1.72 & 3.95 \\
\hline & 300 & 1.93 & 5.14 & 200 & 2.72 & 4.13 \\
\hline & & & & 250 & 2.98 & 4.10 \\
\hline \multirow[t]{5}{*}{ Gaura } & 0 & 0.25 & 0.62 & 50 & 1.45 & 2.67 \\
\hline & 100 & 1.04 & 3.03 & 100 & 2.08 & 2.60 \\
\hline & 200 & 1.25 & 3.67 & 150 & 2.74 & 3.33 \\
\hline & 300 & 1.75 & 4.76 & 200 & 1.57 & 3.52 \\
\hline & & & & 250 & 3.34 & 3.42 \\
\hline \multirow[t]{5}{*}{ Salvia } & 0 & 0.23 & 一 & 50 & 1.27 & 2.94 \\
\hline & 100 & 0.85 & 3.09 & 100 & 1.34 & 3.74 \\
\hline & 200 & 1.44 & 4.46 & 150 & 2.20 & 5.16 \\
\hline & 300 & 1.79 & 4.61 & 200 & 2.55 & 5.42 \\
\hline & & & & 250 & 3.88 & 6.13 \\
\hline \multirow[t]{5}{*}{ Perovskia } & & & & 50 & 0.55 & 3.88 \\
\hline & & & & 100 & 0.72 & 3.79 \\
\hline & & & & 150 & 1.39 & 3.81 \\
\hline & & & & 200 & 1.75 & 4.77 \\
\hline & & & & 250 & 2.65 & 4.56 \\
\hline
\end{tabular}

${ }^{\mathrm{z}} \mathrm{l} \mathrm{mg} \cdot \mathrm{L}^{-1}=1 \mathrm{ppm}, \mathrm{l} \mathrm{dS} \cdot \mathrm{m}^{-1}=1 \mathrm{mmho} / \mathrm{cm}$.

little benefit from the higher $\mathrm{N}$ rates, but the 0 and $50 \mathrm{mg} \cdot \mathrm{L}^{-1} \mathrm{~N}$ treatments produced the lowest number of potential cuttings across all species. Similarly, rates of 250 to $300 \mathrm{mg} \cdot \mathrm{L}^{-1} \mathrm{~N}$ tended to reduce the number of potential cuttings or the lifespan of the stock plants. Our results indicate overall performance of stock plants and cuttings for these four species was generally optimized with the 100 and $150 \mathrm{mg} \cdot \mathrm{L}^{-1} \mathrm{~N}$ treatments and produced the highest number of quality rooted cuttings.

\section{Literature cited}

Arsenault, J.L., S. Pouleur, C. Messier, and R. Guay. 1995. WinRHIZO, a rootmeasuring system with a unique overlap correction method. HortScience 30:906 (abstr.).

Cerveny, C.E., J.L. Gibson, and J.E. Barrett. 2005. Impact of nitrogen concentration on stock plant yield and cutting performance of 'Purple Small Leaf' and 'Raspberry Ice' bougainvilleas. Proc. Intl. Plant Prop. Soc. 55:550-555.

Druege, U., F. Zerche, and R. Kadner. 2000. Relation between nitrogen and soluble carbohydrate concentrations and subsequent rooting of chrysanthemum cuttings as affected by pre-harvest nitrogen supply and cold-storage. Ann. Bot. (Lond.) 85:687-701.

Ganmore-Neumann, R. and A. Hagiladi. 1992. Plant growth and cutting production of container-grown pelargonium stock plants as affected by $\mathrm{N}$ concentration and $\mathrm{N}$ form. J. Amer. Soc. Hort. Sci. 117:234-238.

Gibson, J.L. 2003. Influence of mineral nutrition on stock plant yield and subsequent rooting of stem cuttings of scaevola, new guinea impatiens, and vegetative strawflower. Dissertation, North Carolina State University. 10 Aug. 2011. <http:// repository.lib.ncsu.edu/ir/bitstream/ 1840.16/3741/1/etd.pdf>.

Gibson, J.L. and C.B. Cerveny. 2005. Stock plant production and management basics for small greenhouse businesses. Univ. of Florida, Inst. Food Agr. Sci. ENH1021.

Henry, P.H., F.A. Blazich, and L.E. Hinesley. 1992. Nitrogen nutrition of containerized eastern redcedar. II. Influence of stock plant fertility on adventitious rooting of stem cuttings. J. Amer. Soc. Hort. Sci. 117:568-570.

Raymer, J., M. Thetford, and D.L. Miller. 2008. Fertility rate of seacoast marshelder stock plants influences cutting production and rooting characteristics of stem cuttings. HortTechnology 18:372-378.

Rowe, D.B. and B.M. Cregg. 2002. Effect of incorporating controlled-release fertilizer on growth during adventitious rooting of artemisia, gaura, and nepeta. J. Environ. Hort. 20(1):1-6.

Rowe, D.B., F.A. Blazich, and R.J. Wier. 1999. Mineral nutrient and carbohydrate status of loblolly pine during mist propagation as influenced by stock plant nitrogen fertility. HortScience 34:1279-1285.

Rowe, D.B., F.A. Blazich, and C.D. Raper. 2002a. Nitrogen nutrition of hedged stock plants of loblolly pine. I. Tissue nitrogen concentrations and carbohydrate status. New For. 24(1):39-52.

Rowe, D.B., F.A. Blazich, F.C. Wise, and B. Goldfarb. 2002b. Nitrogen nutrition of hedged stock plants of loblolly pine. II. Influence of carbohydrate and nitrogen status on adventitious rooting of stem cuttings. New For. 24(1):53-65.

Scoggins, H.L. 2005. Determination of optimum fertilizer concentration and corresponding substrate electrical conductivity for ten taxa of herbaceous perennials. HortScience 40:1504-1506.

Scoggins, H.L. 2006. Cutting propagation of perennials, p. 173-185. In: J. Dole and J. Gibson (eds.). Cutting propagation of floral crops. Ball Publishing, Batavia, IL.

Zerche, F. and U. Druege. 2009. Nitrogen content determines adventitious rooting in Euphorbia pulcherrima under adequate light independently of pre-rooting carbohydrate depletion of cuttings. Sci. Hort. 121:340-347. 